\begin{tabular}{|l|l|l||}
\hline \multicolumn{2}{|c|}{ PublisherInfo } \\
\hline \hline PublisherName & $:$ & BioMed Central \\
\hline \hline PublisherLocation & $:$ & London \\
\hline \hline PublisherImprintName & $:$ & BioMed Central \\
\hline \hline
\end{tabular}

\title{
Breast cancer mouse
}

\begin{tabular}{||l|l|l||}
\hline \multicolumn{2}{|c|}{ ArticleInfo } \\
\hline \hline ArticleID & $:$ & 4097 \\
\hline \hline ArticleDOI & $:$ & $10.1186 /$ gb-spotlight-20010524-03 \\
\hline \hline ArticleCitationID & $:$ & spotlight-20010524-03 \\
\hline \hline ArticleSequenceNumber & $:$ & 168 \\
\hline \hline ArticleCategory & $:$ & Research news \\
\hline \hline ArticleFirstPage & $:$ & 1 \\
\hline \hline ArticleLastPage & $:$ & 2 \\
\hline \hline & & RegistrationDate : 2001-05-24 \\
ArticleHistory & $:$ & OnlineDate $\quad$ 2001-05-24 \\
\hline \hline ArticleCopyright & $:$ & BioMed Central Ltd2001 \\
\hline \hline ArticleGrants & $:$ & \\
\hline \hline ArticleContext & $:$ & 130592211 \\
\hline \hline
\end{tabular}




\section{Jonathan B Weitzman}

Email: jonathanweitzman@hotmail.com

In mice, null mutations of the breast cancer susceptibility gene Brcal result in embryonic lethality. In the May 15 Genes \& Development, Ludwig et al. describe the generation of a mutant mouse that expresses a truncated Brca1 protein that mimics mutations found in human breast cancer patients (Genes \& Development 2001, 15:1188-1193). They used a two-step 'knock-in' targeting strategy to insert a stop codon in Brcal exon 11. The genetic background of the mice determined the extent of embryonic lethality. Surviving mice homozygous for the truncated Brcal allele developed tumours at high frequency (about 85\%) at around 17 months of age. The tumour spectrum included lymphomas, sarcomas, and carcinomas, and histologically diverse breast carcinomas developed in some mutant mice. The authors speculate that the truncated Brcal protein plays a role in the late stages of tumour progression.

\section{References}

1. In search of the tumour-suppressor functions of BRCA1 and BRCA2.

2. The tumor suppressor gene Brcal is required for embryonic cellular proliferation in the mouse.

3. Genes \& Development, [http://www.genesdev.org] 